\title{
Modelling and measurement of two-layer-canopy interception losses in a subtropical evergreen forest of central-south China
}

\author{
G. Zhang ${ }^{1,2}$, G. M. Zeng ${ }^{1}$, Y. M. Jiang ${ }^{1,2}$, G. H. Huang ${ }^{1}$, J. B. Li ${ }^{1}$, J. M. Yao ${ }^{3}$, W. Tan ${ }^{1}$, R. Xiang ${ }^{4}$, and X. L. Zhang ${ }^{1}$ \\ ${ }^{1}$ College of Environmental Science and Engineering, Hunan University, Changsha, 410082, P.R. China \\ ${ }^{2}$ Hunan Environment Protection Bureau, Changsha, 410082, P.R. China \\ ${ }^{3}$ Xiangya College, Central South University, Changsha, 410081, P.R. China \\ ${ }^{4}$ Hunan Research Academy of Environmental Sciences, Changsha, 410041, P.R. China
}

Received: 17 August 2005 - Published in Hydrology and Earth System Sciences Discussions: 20 September 2005

Revised: 5 December 2005 - Accepted: 19 December 2005 - Published: 9 February 2006

\begin{abstract}
The original Gash analytical model and the sparse Gash's model were combined to simulate rainfall interception losses from the top- and sub-canopy layers in Shaoshan evergreen forest located in central-south China in 2003. The total estimated interception loss from the two canopy layers was $334.1 \mathrm{~mm}$ with an overestimation of $39.8 \mathrm{~mm}$ or $13.5 \%$ of the total measured interception $(294.3 \mathrm{~mm})$. The simulated interception losses of the top- and sub-canopy suggested that the simulated interception losses in the stages of "during storms" and "after storms" were in good agreement with the published ones. Both the original Gash model and the sparse model overestimated the interception losses, but the sparse model gave more accurate estimates than the original Gash model.
\end{abstract}

\section{Introduction}

Canopy interception loss, the proportion of incident precipitation that is intercepted, stored and subsequently evaporated from the leaves, branches and stems of vegetation, is a significant and sometimes a dominant component of evapotranspiration from forest stands (Gash, 1979; Dolman, 1988; Hörmann et al., 1996; Acreman, 2003). Canopy interception loss is approximated as the difference between incident precipitation measured above the canopy and the sum of throughfall and stemflow below the canopy (Lloyd, et al., 1988; Mahendrappa, 1990; Tobón et al., 2000). Much forest research on forest canopy interception showed that it can account for $10 \sim 35 \%$ of gross precipitation (Wright et al., 1990; Whitehead and Kelliher, 1991; Thimonier, 1998; Zeng et al., 2005). But interception varies greatly among tree species, forest density, canopy structure, vegetation physiology and different climatic conditions. Interception can be as

Correspondence to: G. M. Zeng

(zgming@hnu.cn, ee-307@hotmail.com) high as $50 \%$ of rainfall in some areas (Calder, 1990; Lankreijer et al., 1993).

Gash (1979) proposed a rainfall interception model, which is essentially an analytical form of Rutter model (Rutter et al., 1975). The Gash model retains some of the simplicity of an empirical approach, and also preserves much of the fundamental physical reasoning explicit in the Rutter model. The original Gash model (Gash, 1979) demonstrated that the evaporation of the intercepted rainfall could be estimated from the forest structure, the mean evaporation, rainfall rates and rainfall pattern. Although the model has been used with some success over various forests (Leyton et al., 1967; Lloyd et al., 1988; Hutjes et al., 1990; Dykes, 1997; Valente et al., 1997; Aboal et al., 1999; Jackson, 2000; Price and CarlyleMoses, 2003), the model in less suited for application in the sparse forests (Lankreijer et al., 1993; Gash et al., 1995). The original Gash model tends in theory to overestimate the interception loss from sparse forests as it is assumed that the evaporation area (canopy and trunks) extends to the whole plot area, whereas the actual evaporating area is greatly reduced in these types of forests (Teklehaimonot and Jarvis, 1991). To account for this weakness, Gash et al. (1995) and Valente et al. (1997) revised the original model for the application to sparse forests.

Neither the original Gash model (Gash, 1979) nor the reformulated versions (Gash et al., 1995; Valente et al., 1997) have been applied to the subtropical forests in China. Shaoshan forest canopy is with two-layer structure, where the projected top-canopy coverage of the stand is $82 \%$ and that of the sub-canopy coverage is $41 \%$ (Zhang et al., 2005). Due to the two-layer structure, application of a single Gash model in Shaoshan forest is likely to be problematic. Considering the nature of Gash models and the height and coverage of each canopy layer, we are inclined to use the original Gash model to estimate the top-canopy interception loss and the sparse model to estimate the sub-canopy loss. Kelliher et al. $(1986,1990)$ studied the evaporation from the understory

(C) 2006 Author(s). This work is licensed under a Creative Commons License. 


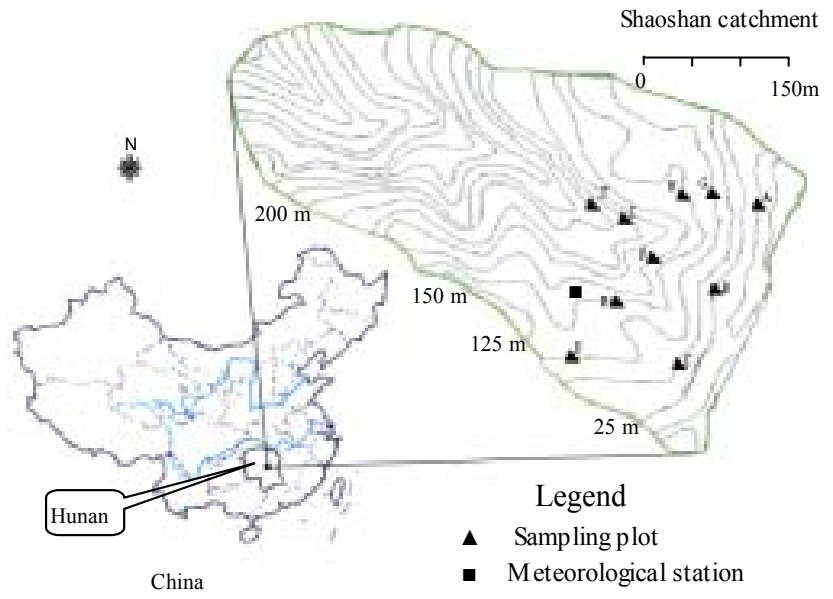

Fig. 1. Location of the studied site and distribution of 10 plots.

in the two young Pinus radiato D. Don stands and a Douglas forest, but the evaporation loss from the sub-canopy layer was often ignored (Hörmann et al., 1996; Carlyle-Moses and Price, 1999; Gash et al., 1999; Carlyle-Moses, 2004). The combination of the original and sparse Gash models to predict the canopy interception losses in our present study is a first for the forest hydrological studies.

The quantitative effects of woodland on water resources are largely dependent on interception loss (Jetten, 1996; Calder and Hall, 1997), since forest canopies typically intercept the majority of rainfall, and control its subsequent evaporation and drainage (Carlyle-Moses and Price, 1999; Barbour et al., 2005). The availability of water directly influences the vitality and growth of forest by limiting the transpiration (Rowe, 1983; Price and Carlyle-Moses, 2003; Cui et al., 2005). If the interception loss models, such as the Gash analytical models, can be applied to the forests in China, this would provide watershed managers with a valuable tool for evaluation of the hydrologic impacts on the forest ecosystem.

The objectives of this research are: (i) to estimate the various climatological and stand parameters required in the original Gash model and the sparse Gash model for top- and subcanopy layer when applied to Shaoshan forest, (ii) to assess the appropriateness of the two types of models, in particular to determine whether the combined model provide the better estimates of canopy interception losses when compared to single studying independent models.

\section{Materials and methods}

\subsection{Site description}

The study site of Shaoshan forest (27 ha) is located in the hills in central Hunan province, central-south China $\left(27^{\circ} 51^{\prime} \mathrm{N}, 112^{\circ} 24^{\prime} \mathrm{E}\right)$. The experimental plots vary in elevation between 25 and $290 \mathrm{~m}$. The forest lies $30 \mathrm{~km}$ from

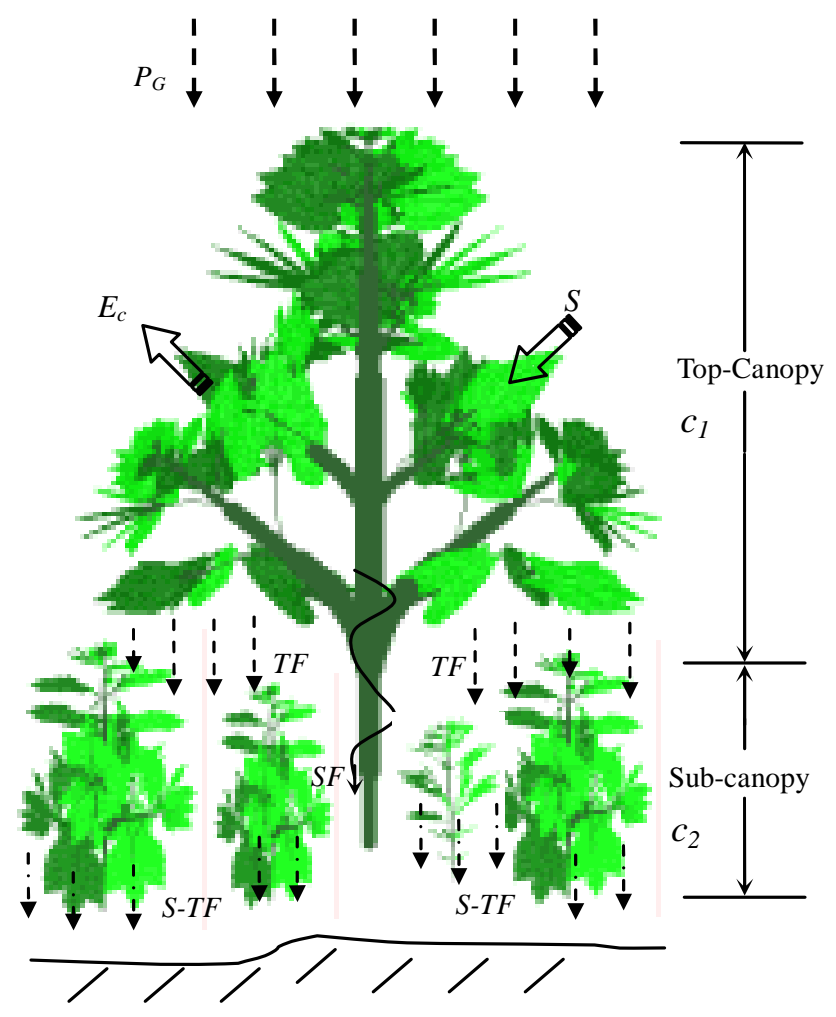

Fig. 2. Schematic diagram of the two-layer structure canopy and canopy water components in Shaoshan forest.

the nearest town Xiangtan city (600 thousand inhabitants) (Fig. 1).

\subsection{Climate}

Owing to the effect of the monsoon from the Pacific and Indian Oceans, the climate of Hunan is the humid monsoon subtropics, with four seasons a year, i.e. spring (March to May), summer (June to August), autumn (September to November), and winter (December to February). About 20\% of the annual rainfall falls in spring and $60 \%$ in summer. Summer is very humid (90\%), while autumn and winter are the dry and have short periods of rain. The annual mean precipitation is $1200-1500 \mathrm{~mm}$ and the annual mean temperature is $17.0^{\circ} \mathrm{C}$, with an absolute maximum of $39^{\circ} \mathrm{C}$ in August and an absolute minimum of $-2.0^{\circ} \mathrm{C}$ in January.

\subsection{Vegetation}

The projected top-canopy coverage of the stand is $\sim 82 \%$ and that of the sub-canopy coverage is $41 \%$. The age of the forest trees is 20 40-year-old. The species in Shaoshan forest form two-layer canopies, the top-canopy and the sub-canopy layer (Fig. 2). As to the top-canopy-layer components, Chinese fir (Cunninghamia lanceolata) dominates the stand, and massoniana pine (Pinus Massoniana) and camphor wood 
(Cinnamomum camphora) are frequent species; in addition, some bamboos (Phyllostachys pubescens) grow here. The four species make up approximate $93 \%$ of the density and $90 \%$ of the relative dominance of the top-canopy layer in the study stand (Table 1). The top-canopy layer, with an approximate height of $10-30 \mathrm{~m}$, is dominated by the four species crowns, while the sub-canopy layer, which ranges from approximate $0.8-3.5 \mathrm{~m}$ in height, is comprised of the crowns of all tree species found within the plot. The species of camellia (Camellia japonica), oleander (Nerium indicum) and holly (Euonumus japonicus), Ternstroemia (Ternstroemia gymnanthera) dominate the sub-canopy layer.

\subsection{Measurements of throughfall and stemflow}

Data were collected from ten $30 \times 30 \mathrm{~m}^{2}$ plots in the subtropical evergreen Shaoshan forest. The procedures of sampling and design in Shaoshan forest stand were taken from the manual of EMEM (1996). From a total of 10 (A-J plot) plots in the studied forest, 3 plots (A-C plot) are set in the lower parts of the forest (25-50 $\mathrm{m}$ a.s.l., above sea level), 5 plots (D-H plot) in the middle parts (75-100 $\mathrm{m}$ a.s.1.) and 2 plots (I-J plot) in the upper parts (125-170 m a.s.l.) (Fig. 1). In each plot, 16 canopy throughfall collectors were randomly placed under the canopy and $1.0 \mathrm{~m}$ above the ground, and 4 sub-canopy throughfall collectors were placed under the subcanopy and $0.20 \mathrm{~m}$ above the floor. The throughfall collector is made of a $2 \mathrm{~L}$ plastic bottle, a plastic funnel $(\mathrm{d}=11.5 \mathrm{~cm})$, a connector with a filter (nylon screen) and a mounting equipment. Stemflow from each tree was diverted from the corrugated collar to a collection container at base of each tree. Halved plastic corrugated tubing $(\sim 2.5 \mathrm{~cm}$ wide) was stapled and sealed with caulking around the circumference of 8 trees at a mean height of $\sim 1.5 \mathrm{~m}$. The stemflow $(\mathrm{mm})$ was derived employing the equation (Price and Carlyle-Moses, 2003):

$$
S F=\frac{n \cdot S F(a)}{F A}
$$

where $S F$ is the estimated stemflow for a given area of forest $(F A)\left(\mathrm{m}^{2}\right)$ with $n$ number of trees $(n=8)$ and $S F(a)$ is the average stemflow volume from sampled trees.

\subsection{Meteorological instruments}

A weather station was fixed $\sim 5.0 \mathrm{~m}$ above the top of the canopy on a $30 \mathrm{~m}$ metal tower, which included a wet-only collector MISU (Department of Meteorology, Stockholm University, Sweden) and an Eddy Correlation (ECOR) System. The ECOR system includes a 3-D sonic anemometer (Gill Instruments Ltd. Omnidirectional Model R3) and a LI6262 closed path infrared gas analyzer (LI-COR, Lincoln, Nebraska). The data from ECOR system were sampled every second and averaged $10 \mathrm{~min}$ are periods. Rainfall volumes and rainfall intensity were measured at a half-hour interval. In this study, the detailed half-hour data from two typical
Table 1. Density, basal area and relative dominance of tree species within the study plot.

\begin{tabular}{|c|c|c|c|c|}
\hline Vegetation type & $\begin{array}{l}\text { Density } \\
\left.\text { (trees ha }^{-1}\right)\end{array}$ & $\begin{array}{l}\text { Mean } \\
\text { D.B.H. } \\
(\mathrm{cm})\end{array}$ & $\begin{array}{l}\text { Basal area } \\
\left(\mathrm{m}^{2} \mathrm{ha}^{-1}\right)\end{array}$ & $\begin{array}{l}\text { Relative } \\
\text { dominance } \\
(\%)\end{array}$ \\
\hline \multicolumn{5}{|l|}{ Top-canopy layer } \\
\hline China Fir & $134 \pm 10.2$ & $45.2 \pm 3.9$ & $22.6 \pm 2.6$ & $42.0 \pm 4.1$ \\
\hline Massoniana & $108 \pm 8.8$ & $34.1 \pm 3.4$ & $18.7 \pm 1.8$ & $30.2 \pm 3.5$ \\
\hline Camphor wood & $66 \pm 6.1$ & $76.3 \pm 6.8$ & $4.5 \pm 0.9$ & $18.8 \pm 2.2$ \\
\hline Bamboos & $55 \pm 4.9$ & $20.5 \pm 2.9$ & $3.3 \pm 0.7$ & $5.0 \pm 1.5$ \\
\hline \multicolumn{5}{|l|}{ Sub-canopy layer } \\
\hline Camellia & $45 \pm 4.7$ & $3.5 \pm 0.8$ & $2.1 \pm 0.7$ & $25.1 \pm 4.6$ \\
\hline Oleander & $32 \pm 4.0$ & $6.4 \pm 1.1$ & $1.5 \pm 0.5$ & $20.2 \pm 3.7$ \\
\hline Holly & $30 \pm 3.5$ & $5.0 \pm 0.9$ & $0.6 \pm 0.2$ & $18.6 \pm 2.6$ \\
\hline Ternstroemia & $15 \pm 2.8$ & $5.5 \pm 1.0$ & $0.8 \pm 0.2$ & $7.4 \pm 1.1$ \\
\hline
\end{tabular}

events: 15-17 April and 28-30 October in 2003 were used, as well as standard meteorological data averaged weekly.

\section{Descriptions of the models}

\subsection{The original Gash model}

The original model of Gash (1979) considers rainfall to occur as a series of discrete events, during which three phases can be distinguished: (i) a wetting phase; (ii) a saturation phase and (iii) a drying phase after rainfall has ceased. The model is usually calculated from the total daily rainfall, assuming one storm per day (Gash, 1979). The canopy is assumed to have sufficient time to dry between storms. Therefore, the model was not intended to be used for short vegetation types in temperate latitudes, which may stay wet for prolonged periods of time (van Dijk and Bruijnzeel, 2001). The original Gash model has been successfully applied to simulate canopy interception loss in relatively closed canopies (canopy covers from $60 \%$ to $100 \%$ ). The model of the evaporative process assumes that the canopy and trunk storages extend to the whole plot area (Gash and Morton, 1978; Gash et al., 1980; Pearce and Rowe, 1981; Lloyd et al., 1988; van Dijk and Bruijnzeel, 2001). Consequently the results from some other studies suggested that these models should not be applied to the sparse forests, as they significantly overestimated the interception loss (e.g. Lankreijer et al., 1993).

The forest structure is described in terms of a canopy capacity, $S$ (Gash and Morton, 1978), and a free throughfall coefficient, $p$ ( $p$ is often assumed equal to one minus the canopy cover, $c)$. More often $\left(1-p-p_{t}\right)$ is considered equal to canopy cover, where $p_{t}$ denotes the rainfall diverted to the trunks, which represents a stem storage capacity, $S_{t}(\mathrm{~mm})$. The mean evaporation rate during rainfall, $\bar{E}\left(\mathrm{~mm} \cdot \mathrm{h}^{-1}\right)$, and the mean rainfall rate, $\bar{R}\left(\mathrm{~mm} \cdot \mathrm{h}^{-1}\right)$, for saturated canopy, are also required. The way separate components of the 
Table 2. Original form of the Gash's analytical model compared with the form of the sparse Gash's model revised by Valente et al. (1997).

\begin{tabular}{|c|c|c|}
\hline & $\begin{array}{l}\text { Original Gash (1979) } \\
\text { model }\end{array}$ & Sparse Gash model (Valente et al., 1997) \\
\hline \multicolumn{3}{|l|}{ Components of interception loss } \\
\hline For $m$ storms insufficient to saturate the canopy $\left(P_{G}<P_{G}{ }^{\prime}\right)$ & $\left(1-p-p_{t}\right) \sum_{j=1}^{m} P_{G, j}$ & $c \sum_{j=1}^{m} P_{G, j}$ \\
\hline \multicolumn{3}{|l|}{ For $n$ storms $\left(P_{G} \geq P_{G}{ }^{\prime}\right)$} \\
\hline Wet canopy evaporation during storms & $\frac{\bar{E}}{\bar{R}} \sum_{j=1}^{n}\left(P_{G, j}-P_{G}^{\prime}\right)$ & $\left.\frac{c(1-\varepsilon) \bar{E}_{c}}{\bar{R}} \sum_{j=1}^{n}\left(P_{G, j}-P_{G}^{\prime}\right)\right]$ \\
\hline Evaporation after storms & $n S$ & $n S_{c}$ \\
\hline $\begin{array}{l}\text { Evaporation from trunks for } q \text { storms }\left(P_{G}>S_{t} / p_{t}\right) \text {, } \\
\text { which saturate the trunks and in the left column for the } \\
n+m-q \text {, which do not }\left(P_{G}<S_{t} / p_{t}\right) \\
\text { Parameters }\end{array}$ & $q S_{t}+p_{t} \sum_{j=1}^{m+n-q} P_{G, j}$ & $q S_{t}+p_{d} c\left[1-\frac{(1-\varepsilon) \bar{E}_{c}}{\bar{R}}\right] \sum_{j=1}^{n-q}\left(P_{G}, j-P_{G}^{\prime}\right)$ \\
\hline Rainfall necessary to saturate the canopy $\left(P_{G}^{\prime}\right)$ & $-\frac{\bar{R} S}{\bar{E}} \ln \left[1-\frac{\bar{E}}{\left(1-p-p_{t}\right) \bar{R}}\right]$ & $-\frac{\bar{R}}{(1-\varepsilon) \bar{E}_{c}} \frac{S}{c} \ln \left[1-\frac{(1-\varepsilon) \bar{E}_{c}}{\bar{R}}\right]$ \\
\hline $\begin{array}{l}\text { Mean wet canopy evaporation rate } \\
\text { Canopy capacity }\end{array}$ & $\begin{array}{l}\bar{E}=\bar{E}_{W} \\
S\end{array}$ & $\begin{array}{l}\bar{E}=c \bar{E}_{c} \\
S=c S_{c}\end{array}$ \\
\hline
\end{tabular}

interception losses are calculated using these parameters is shown in Table 2.

\subsection{The sparse Gash model}

Addressing both the conceptual error in the original model and the inadequate performance in the sparse forests (Teklehaimonot and Jarvis, 1991), Gash et al. (1995) proposed a revised version. Valente et al. (1997) further improved the Gash model by taking the canopy sparseness into consideration by scaling the mean evaporation rate during a storm event and other model parameters to the proportion of canopy cover present at the community of interest. The average evaporation $(\bar{E})$ from the saturated canopy is calculated, as in the original version of the model, through the PenmanMonteith equation. Evaporation from the open area is assumed to be zero. Valente et al. (1997) replaces the evaporation from the canopy term $\left(\bar{E}_{c}\right)$ with a term that includes both evaporation from the canopy and trunks, $(1-\varepsilon) \bar{E}_{c}$, where $\varepsilon$ is a model constant relating trunk evaporation to canopy evaporation (Table 2).

\subsection{Estimation of canopy-structure parameters}

\subsubsection{Canopy storage capacity in each canopy layer}

The canopy storage capacity $(S)$ was calculated from a plot of throughfall plus stemflow versus gross precipitation (Aboal et al., 1999). Valente et al. (1997) suggests that the trunks storage capacity $\left(S_{t}\right)$ of the site may be estimated as the negative interception of linear regression with stemflow as the dependent variable and $\left[T F-(1-c) P_{G}\right]$ as the independent variable. While the drainage portioning coefficient $\left(p_{d}\right)$ is equated with the slope of this linear equation divided by $\left(1+\right.$ the slope). The parameters $\bar{E}, S$, and $S_{t}$ are all scaled to the fractional cover (c): $\bar{E}_{c}, S_{c}$, and $S_{t, c}$.

\subsubsection{Evaporation rate}

The measured evaporation rate, $\bar{E},\left(\mathrm{~mm} \cdot \mathrm{h}^{-1}\right)$ is compared with the estimated evaporation for calibration. $\bar{E}_{c}$, the corrected average evaporation rate over the hours of rainfall on one day equals to $\bar{E} \cdot c\left(\mathrm{~mm} \cdot \mathrm{h}^{-1}\right)$. Potential evaporation $\left(E_{p}\right)$ is calculated using the Penman-Monteith equation (Rutter et al., 1971), which is equivalent to the equation with $r_{s}$ set to zero. The aerodynamic conductance $\left(g_{a}\right)$ was calculated from the equation for momentum transfer in near neutral conditions (Gash et al., 1999):

$g_{a}=\left\{\frac{k}{\ln \left[(z-d) / z_{0}\right]}\right\}^{2} \cdot u$

where $k$ is von Kámán's constant $(k=0.41), d(\mathrm{~m})$ is the zero plane displacement, $z_{0}(\mathrm{~m})$ is the roughness for momentum and $u\left(\mathrm{~m} \cdot \mathrm{s}^{-1}\right)$ is the windspeed at height $z(\mathrm{~m}) . d$ and $z_{0}$ were estimated as 0.75 and 0.1 , respectively, of the average stand height (Rutter et al., 1971, 1975).

Evaporation rate $(E)$ for the saturated canopy of a sparse forest can be estimated as $E_{p}$ when $C \geq S$, or as $E=E_{p} \cdot C / S$, when $C<S$ ( $C$ is the actual canopy storage and $S$ is canopy storage capacity) (Teklehaimonot and Jarvis, 1991; Domingo et al., 1998; Schellekens, et al., 1999). 


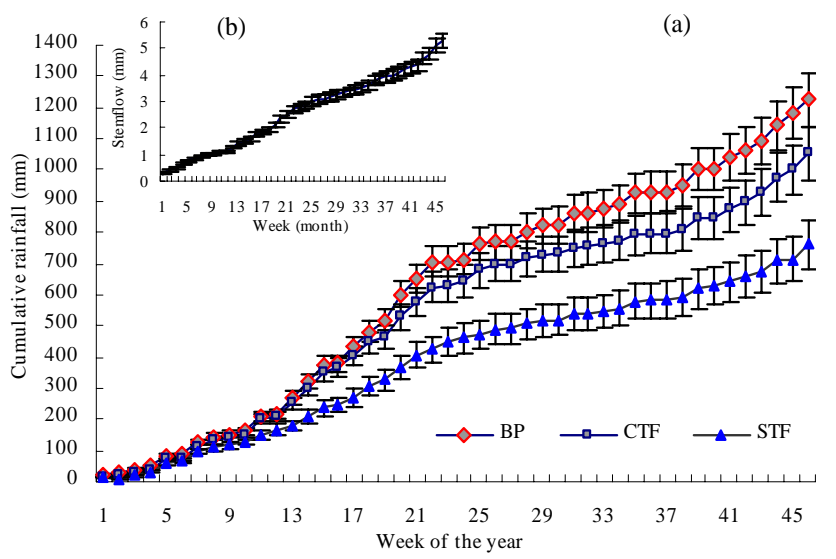

Fig. 3. Cumulative measured precipitation (BP), throughfall (CTF) and sub-throughfall (STF) (a), and stemflow (b) in 2003.

Rainfall intensity, $R$, is calculated for all hours when the rainfall exceeds the threshold, $0.5 \mathrm{~mm}$ (Gash et al., 1995).

\subsubsection{Coefficient of free throughfall ( $p)$ and model con- stant $(\varepsilon)$}

The coefficient was estimated by the method of Leyton et al. (1967), as the slope of the regression of single-event throughfall on single event rainfall, in this case considering the event amount necessary exceeds $S$. The model constant $(\varepsilon)$ that relates the evaporation rate from trunks to that of saturated canopies was not determined experimentally. Rather the value of this constant was set to 0.023 based on the findings of Valente et al. (1997).

\subsection{Model calibration and validation}

To calibrate the two models, several rainfall events were selected throughout the year and were put into an artificial sequence of 10 days in total. The events were selected for relatively extreme rainfall intensities and amounts, for low and high evaporation rates at night and during the day, and for low and high temperatures, and for low and high wind velocities. In parameter optimization, mutual interference between parameters is to be eliminated as much as possible.

To test whether one characteristic parameter set can be used throughout the year, the total 10 calibration periods were again split into five original individual periods. For each period, each parameter was again optimized once at a time.

\section{Results}

\subsection{Rainfall partitioning and variability}

During the observed year of 2003 in Shaoshan forest, a total of 75 events were measured adding up to a cumulative

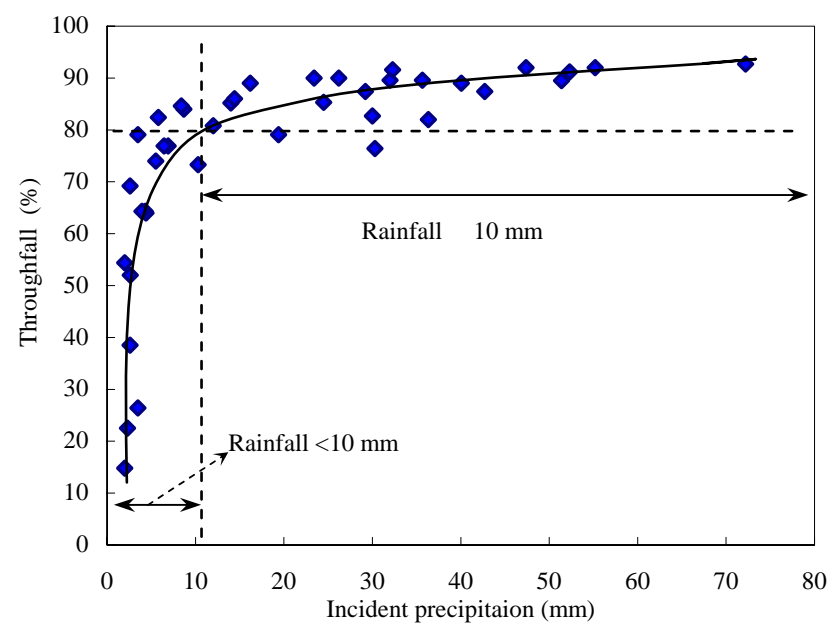

Fig. 4. Throughfall as a percentage of incident precipitation in the study site during the observe year of 2003.

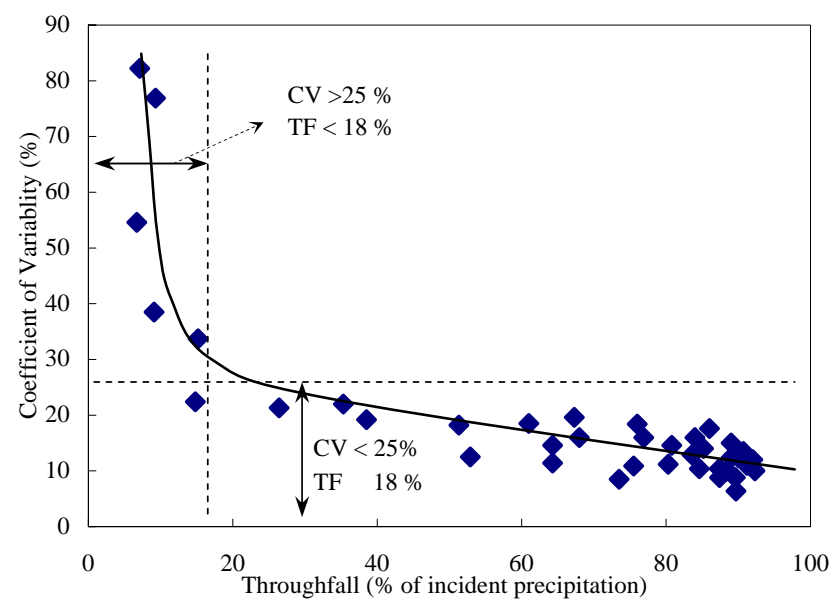

Fig. 5. Throughfall coefficients of variation (CV) (\%) as a function of the throughfall (\% of incident precipitation).

rainfall quantity of $1226 \pm 15.6 \mathrm{~mm} \cdot \mathrm{yr}^{-1}$ (Fig. 3). The cumulative top-canopy throughfall accounted for $84.7 \%$ of $P_{G}$. The cumulative sub-throughfall was measured to be $76.0 \%$ of $P_{G}$ (Fig. 3). The stemflow in the top-canopy amounted to $0.4 \%$ of $P_{G}$. The stemflow in sub-canopy was not measured for field operational reasons.

The variability of the throughfall depths between the gauges ranged from $3.5 \%$ to $18.6 \%$ with a mean of $7.2 \%$. The variability of throughfall between the measured 10 plots was estimated at $12.7 \%$, ranging from $5.6 \%$ to $20.8 \%$.

For the large events $\left(P_{G} \geq 10 \mathrm{~mm}\right)$ in Shaoshan forest stand, throughfall accounted for more than $85 \%$ of the incident precipitation (Fig. 4). The proportion of throughfall for smaller events $\left(P_{G}<10 \mathrm{~mm}\right)$ increased in a linear fashion from $14.1 \%$ for events ranged from 0.4 to $2.0 \mathrm{~mm}$ to $74.8 \%$ for events from 3.4 to $9.4 \mathrm{~mm}$ (Fig. 4). 
2003, April 15-17
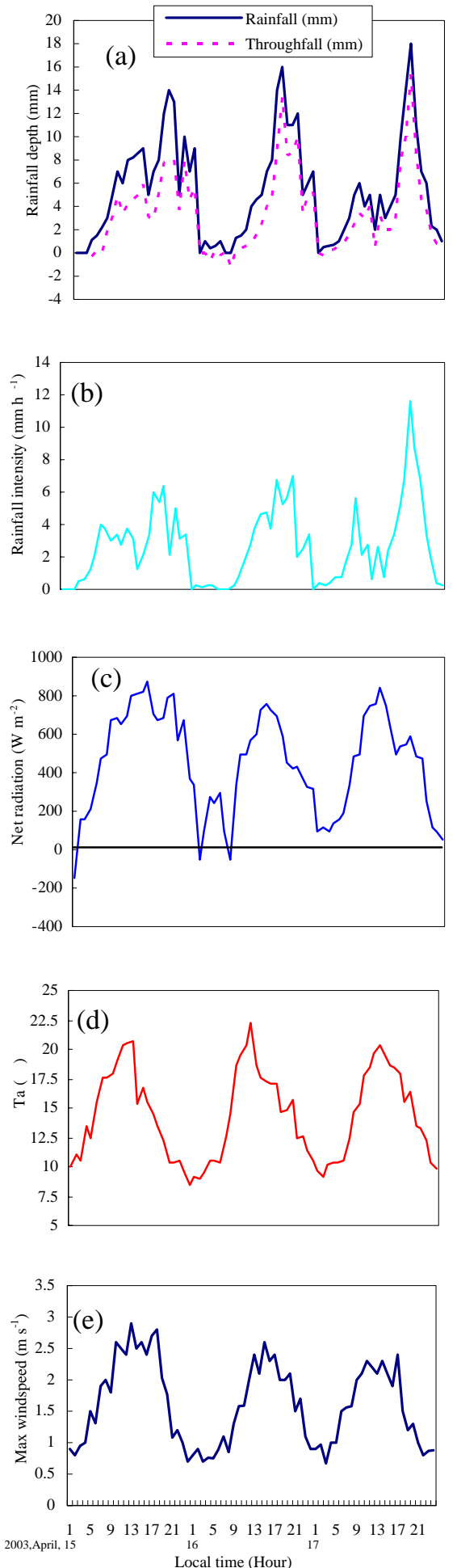

2003, October 28-30
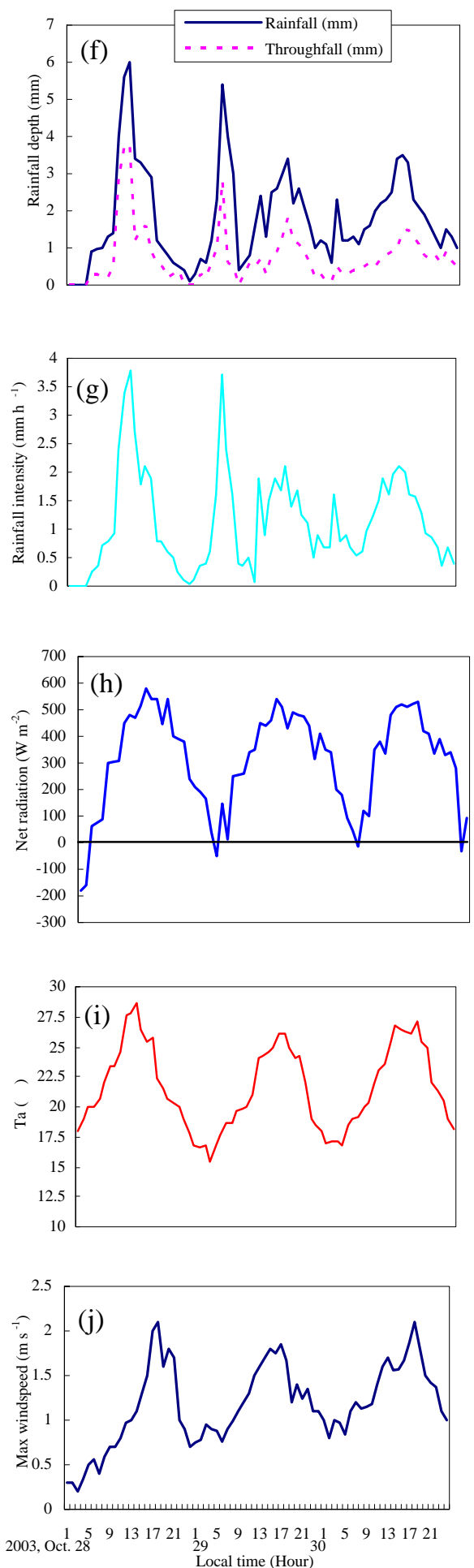

Fig. 6. Detailed half hourly meteorological data for two typical events distributed in 15-17 April and 28-30 October in 2003 in the Shaoshan forest stand. (a), (f): incident rainfall $(\mathrm{mm})$; (b), (g): rainfall intensity $\left(\mathrm{mm} \cdot \mathrm{h}^{-1}\right)$; (c), (h): net radiation $\left(\mathrm{W} \cdot \mathrm{m}^{-2}\right)$; (d), (i): air temperature $\left({ }^{\circ} \mathrm{C}\right) ;(\mathbf{e}),(\mathbf{j})$ : Max windspeed $\left(\mathrm{m} \cdot \mathrm{s}^{-1}\right)$. 

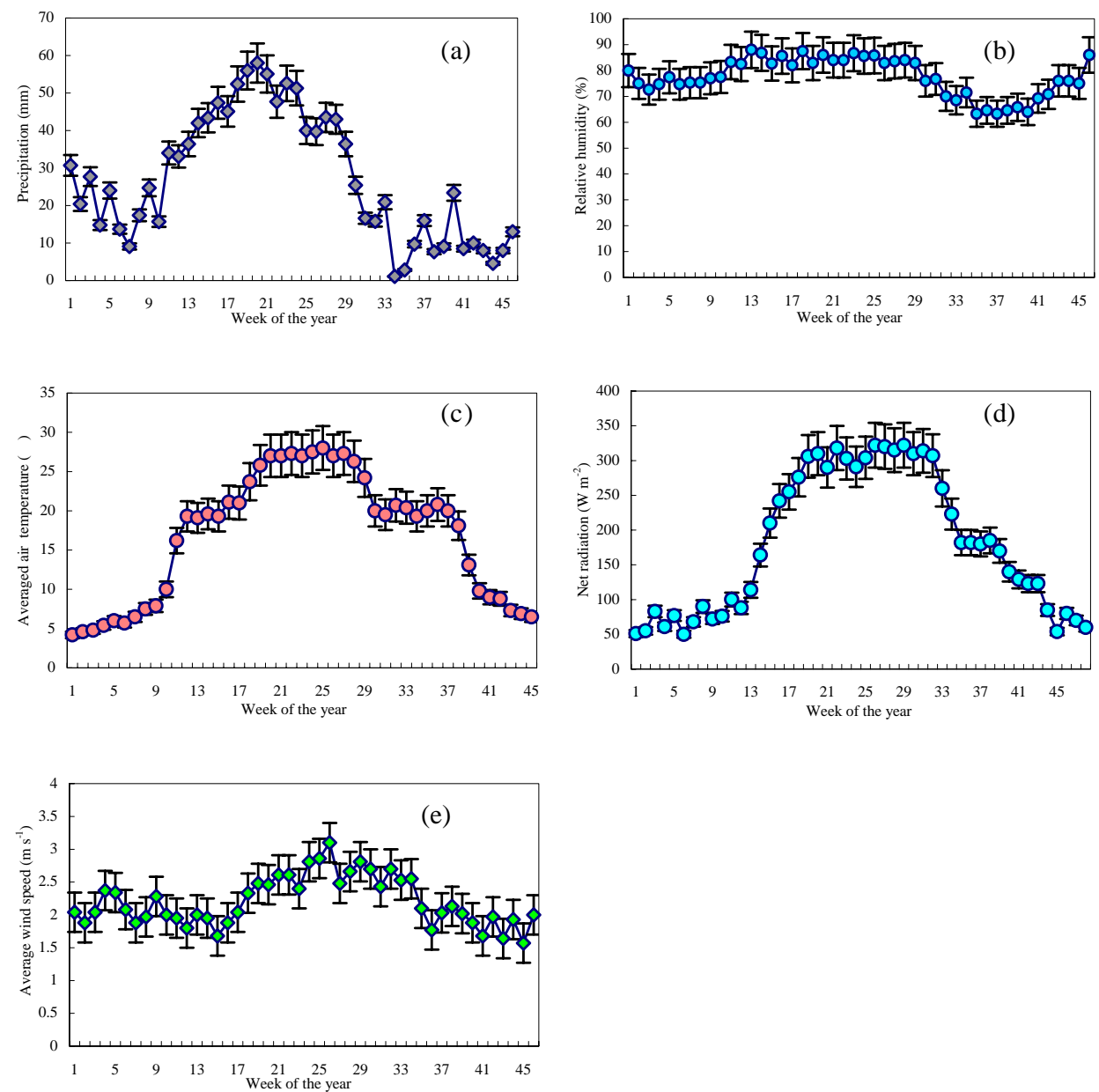

Fig. 7. Weekly averaged precipitation $(\mathrm{mm})(\mathbf{a})$, relative humidity $(\%)(\mathbf{b})$, air temperature $\left({ }^{\circ} \mathrm{C}\right)(\mathbf{c})$, net radiation $\left(\mathrm{W} \cdot \mathrm{m}^{-2}\right)(\mathbf{d})$, and windspeed $\left(\mathrm{m} \cdot \mathrm{s}^{-1}\right)(\mathbf{e})$ in Shaoshan forest during 2003.

The coefficients of variability (CV) of throughfall for all events averaged $11.2 \%$ and ranged from $6.8 \%$ to $81.3 \%$ (Fig. 5). The CV of sub-throughfall for all events were estimated to be $5.5 \%$ and ranged from $2.1 \%$ to $10.7 \%$. The $\mathrm{CV}$ values for small events were much higher than those for large events. The CV values for $\sim 90 \%$ of events, especially for the event precipitation higher than $10 \mathrm{~mm}$, were less than $25 \%$ (Fig. 5).

\subsection{Event weather conditions}

Figure 6 shows the half hourly rainfall and canopy weather data for the events in 15-17 April (wet season) (Fig. 6ae) and 28-30 October (dry season) (Fig. 6d-j), respectively. Both events illustrate the typical time lag of $1-2 \mathrm{~h}$ between significant $P_{G}$ and throughfall, associated with wetting up of the canopy (Fig. 6a and d). Both events show the diurnal cycling of rainfall depth (Fig. 3a and f), rainfall intensity (Fig. $3 \mathrm{~b}$ and g), net radiation (Fig. $3 \mathrm{c}$ and h), temperature (Fig. 3d and i), and max windspeed (Fig. 3e and j). The maximum windspeeds are presented because mechanical dislodging of intercepted water is likely to be a function of the maximum, rather than the mean wind speed. The mean rainfall intensity was measured to be $5.3 \mathrm{~mm} \cdot \mathrm{h}^{-1}$, ranging from $0.3 \mathrm{~mm} \cdot \mathrm{h}^{-1}$ to $12.0 \mathrm{~mm} \cdot \mathrm{h}^{-1}$.

As can be seen from Fig. 7a, 60\% of precipitation was concentrated in the period from week 10th to week 32nd. A similar distribution is found for temperature (Fig. 7b), windspeed (Fig. 7c) and net radiation (Fig. 7d).

\subsection{Canopy structure parameters}

\subsubsection{Canopy storage capacity}

The values of parameters derived for the Gash model versions are presented in Table 3 . The canopy storage capacity $(S)$ appeared to be related to season, increasing from $1.1 \mathrm{~mm}$ in spring and winter to $1.7 \mathrm{~mm}$ (a $54.5 \%$ increase) in summer, with a mean of $1.4 \mathrm{~mm}$ of $S$ in the top-canopy layer 
Table 3. Derived parameters for the Gash models in Shaoshan stand.

\begin{tabular}{lcc}
\hline & Top-canopy layer Original model & Sub-canopy layer Sparse model \\
\hline Gross precipitation, $P_{G}\left(\mathrm{~mm} \mathrm{yr}^{-1}\right)$ & 1226 & 1037 \\
Necessary to saturate canopy, $P_{G}^{\prime}(\mathrm{mm})$ & 1.85 & 1.10 \\
Free throughfall coefficient, $p$ & 0.85 & - \\
Stemflow partitioning coefficient, $p_{t}$ & 0.03 & - \\
Canopy cover, $c$ & 0.82 & 0.41 \\
Canopy storage capacity, $S(\mathrm{~mm})$ & 1.40 & 0.72 \\
Canopy storage scaling by canopy cover, $S_{c}=S / c(\mathrm{~mm})$ & 1.71 & 1.76 \\
Trunk storage capacity, $S_{t}(\mathrm{~mm})$ & 0.16 & 0.09 \\
Average evaporation rate, $\bar{E}\left(\mathrm{~mm} \mathrm{~h}^{-1}\right)$ & 0.79 & - \\
Average evaporation rate scaling by canopy cover, $\bar{E}_{c}\left(\mathrm{~mm} \mathrm{~h}^{-1}\right)$ & - & 0.32 \\
Average rainfall intensity, $\bar{R}\left(\mathrm{~mm} \mathrm{~h}^{-1}\right)$ & 5.3 & 3.8 \\
Number of rainfall sufficient to saturate the canopy, $n$ & 41 & 35 \\
Number of rainfall insufficient to saturate the canopy, $m$ & 8 & 14 \\
Number of rainfall sufficient to saturate the stems and trunks, $q$ & 26 & 15 \\
Constant, $\varepsilon$ & - & 0.023 \\
Drainage partitioning coefficient, $p_{d}$ & - & 0.037 \\
\hline
\end{tabular}

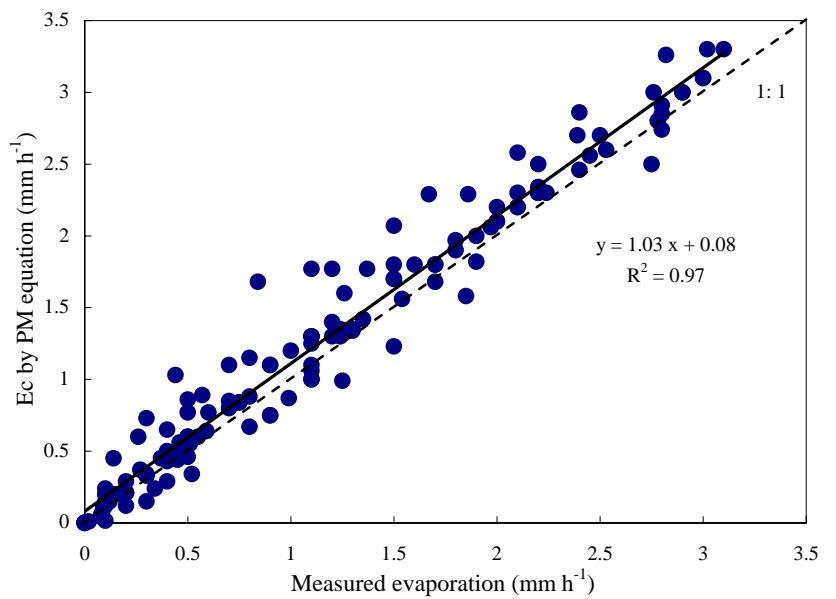

Fig. 8. Comparison of measured and calculated evaporation $\left(\mathrm{mm} \cdot \mathrm{h}^{-1}\right)$ by the eddy correlation system and the Penman-Monteith equation. $\_$is the regression line of the calculated on measured evaporation. The --- is the $1: 1$ line.

(Table 3). The sub-canopy storage capacity, $S$, is estimated to be $0.72 \mathrm{~mm}\left(1.76 \mathrm{~mm}\right.$ for $\left.S_{c}\right)$.

\subsubsection{Canopy evaporation rate}

There is no statistical difference between the measured and calculated evaporation rate by the ECOR systems and the Penman-Monteith equation with Eq. (2). Testing the hypotheses of unit slope and zero intercept showed that the regression line (with a slope of 1.03) is not significant from the $1: 1$ line ( $p$-values of 0.35 and 0.14 for the slope and the intercept, respectively) (Fig. 8). The average evaporation rate per

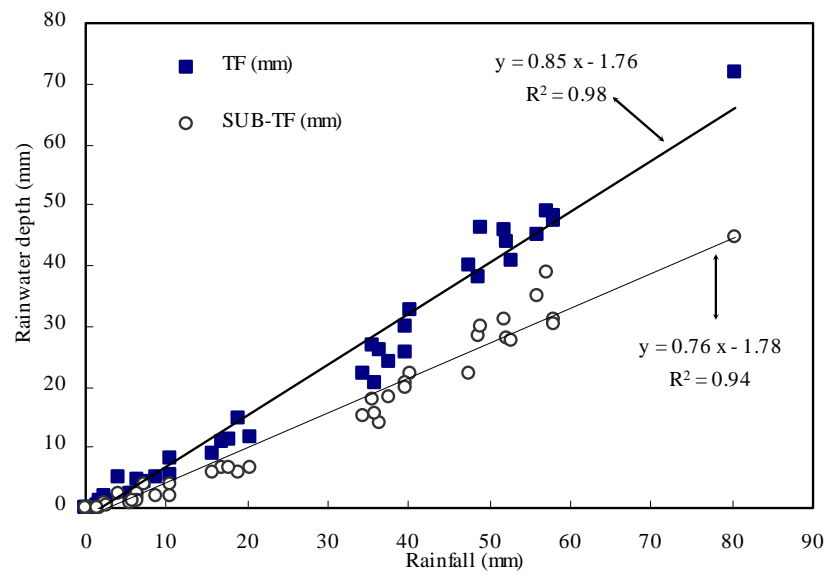

Fig. 9. Relationship between rainfall events and throughfall, and sub-throughfall.

unit ground, $\bar{E}$, was calculated to be $0.79 \mathrm{~mm} \cdot \mathrm{h}^{-1}$ in the topcanopy by the Penman-Monteith equation and $0.32 \mathrm{~mm} \cdot \mathrm{h}^{-1}$ of $\bar{E}_{c}$ for the sparse sub-canopy.

\subsubsection{Free throughfall coefficient}

Free throughfall coefficient $(p)$ for the original Gash model is 0.85 in top-canopy layer by the method of Leyton et al. (1967) and 0.76 in the sub-canopy (Fig. 9), respectively. The stemflow coefficient $\left(p_{t}\right)$ in top-canopy layer was estimated to be 0.03 . 
Table 4. Measured and modelled results of the canopy interception $\left(I_{C}\right)$ components in the studied forest during 2003 (in mm and as $\%$ of total estimated interception loss).

\begin{tabular}{lll}
\hline Parameters & Top-canopy Original model & Sub-canopy Sparse model \\
\hline For storms $P_{G}<P_{G}^{\prime}$ & & \\
Evaporation from canopy & $7.7(3.6 \%)$ & $4.0(3.3 \%)$ \\
For storms $P_{G} \geq P_{G}^{\prime}(\mathrm{mm})$ & & $15.3(12.9 \%)$ \\
Wetting up of canopy & $29.7(13.8 \%)$ & $37.9(32.0 \%)$ \\
Evaporation from canopy during storms & $118.0(54.7 \%)$ & $56.9(48.1 \%)$ \\
Evaporation after storms & $58.7(27.2 \%)$ & $4.4(3.7 \%)$ \\
Evaporation from trunks and stems & $17.5(8.1 \%)$ & 118.5 \\
Estimated interception loss in each canopy layer $(\mathrm{mm})$ & 215.6 & 110.3 \\
Measured interception loss in each canopy layer $(\mathrm{mm})$ & 184.0 & 7.0 \\
Deviation (\%) & 17.2 & 334.1 \\
Total estimated interception loss of two layers $(\mathrm{mm})$ & & 294.3 \\
Total measured interception loss of two layers $(\mathrm{mm})$ & & 13.5 \\
Deviation $(\%)$ & & \\
\hline
\end{tabular}

\subsection{Interception components}

Measured and modelled interception loss components are presented in Table 4. The annual canopy interception loss in the top-canopy layer was measured to be $15.0 \%$ of $P_{G}$ and that in the sub-canopy was $9.0 \%$ of $P_{G}$ during 2003, indicating a total interception loss of $24.0 \%$ of $P_{G}$.

Modeled interception loss from the top-canopy by the original Gash model was $223.6 \mathrm{~mm}\left(18.2 \%\right.$ of $\left.P_{G}\right)$ with an overestimation of $21.5 \%$ compared with the measured loss. Modeled interception in the sub-canopy layer by the sparse Gash model was $118.5 \mathrm{~mm}$, with an overestimation of $7.0 \%$ of the measured loss. The total modelled interception loss was $334.1 \mathrm{~mm}$, with an overestimation of $39.8 \mathrm{~mm}(13.5 \%)$ compared with the total measured loss, $294.3 \mathrm{~mm}$ (Table 4).

The predicted top-canopy interception losses suggested that $54.7 \%$ and $27.2 \%$ of the losses were evaporated in the stages of "during storms" and "after storms", respectively. Similarly, $32.0 \%$ and $48.1 \%$ of the simulated sub-canopy losses were lost in the "during storms" and "after storms" stages, respectively (Table 4).

\subsection{Error analysis}

Error in the field determination of interception losses was estimated assuming that (a) a random error of $5 \%$ in incident event measurement throughout the study year (Gash et al., 1995), giving a total error of $61.3 \mathrm{~mm}$ for top-canopy and $51.2 \mathrm{~mm}$ for sub-canopy, (b) an error of $11.2 \%$ for throughfall and $5.5 \%$ for sub-throughfall, estimated on the basis of its spatial variability, and giving a total error of $19.5 \mathrm{~mm}$ for throughfall and $10.0 \mathrm{~mm}$ for sub-throughfall, and (c) an error of $20 \%$ in stemflow (see Gash et al., 1995) giving a total error of $1.1 \mathrm{~mm}$. The quadratic sum of these errors gives a total error of $64.3 \mathrm{~mm}$, i.e. $37.0 \%$ of the top-canopy inter- ception losses, and a total error of $52.1 \mathrm{~mm}$, i.e. $28.6 \%$ of the sub-canopy interception. It should be noted that his error translates to error in the estimation of canopy parameters, notably $S$ (Gash and Morton, 1978; Lloyd et al., 1988).

Error in the prediction of the top-canopy interception losses with the original Gash model, estimated by following the method of Lloyd et al. (1988), was dominated by the errors in $\mathrm{S}, p, p_{t}$, and $\bar{E}$, which assumed to be $\pm 0.1 \mathrm{~mm}$, $0.5,0.01$, and $0.02 \mathrm{~mm} \cdot \mathrm{h}^{-1}$, respectively. And the error in prediction of sub-canopy interception losses was dominated by errors in $\mathrm{S}_{c}, \bar{E}_{c}$ and $c$, which assumed to be $\pm 0.1 \mathrm{~mm}, 0.01 \mathrm{~mm} \cdot \mathrm{h}^{-1}$ and 0.10 , respectively. The method of Rosenbluth (1975) was used to derive an estimated error of $\pm 13.7 \mathrm{~mm}$ for top-canopy interception losses and $\pm 11.2 \mathrm{~mm}$ for sub-canopy losses, respectively. From what has been discussed above, we can see that the predicted errors are smaller than the observation errors. The sparse Gash model gives more accurate estimates than the original model.

\section{Discussion}

\subsection{Canopy storage capacity}

The derived values of the storage capacity for the original and sparse Gash model in top- and sub-canopy layer are 1.40 and $0.72 \mathrm{~mm}$, respectively. The values fall within the typical range of 0.5 to $2.5 \mathrm{~mm}$ for deciduous canopies and 0.3 to $2.4 \mathrm{~mm}$ for coniferous canopies (Whitehead and Kelliher, 1991; Návar and Bryan, 1994; Klaassen et al., 1998; van Dijk and Bruijnzeel, 2001). The storage capacity is assumed to be constant during a single storm, but is probably variable between events (Robin, 2003; Keim, 2004). The storage capacity tends to increase with smaller drops and lower rainfall rate (Calder, 1990, 1996). The raindrop size in the 
Table 5. Partitioning of interception losses (\%) among the different modelled stages of rainfall events in the Gash models. The results shown for the present study refer to the estimates from the original and sparse Gash models.

\begin{tabular}{lllllll}
\hline Literatures & I & II & III & IV & V \\
\hline & \multicolumn{5}{c}{$I_{C}$ from original Gash model } \\
\cline { 2 - 7 } & 3.6 & 13.8 & 54.7 & 27.2 & 8.1 \\
Present study (top-canopy) & 19 & 5 & 34 & 41 & 1 \\
Gash (1979) & 10 & 3 & 27 & 49 & 11 \\
Gash et al. (1980) & 3 & 4 & 69 & 23 & 1 \\
Pearce and Rowe (1981) & 7 & 1 & 34 & 49 & 9 \\
Lloyd et al. (1988) & 0 & 4 & 71 & 22 & 3 \\
Návar and Bryan (1994) & 4 & 3 & 34 & 54 & 5 \\
Carlyle-Moses and Price (1999) & 0 & 8 & 82 & 10 & 0 \\
Schellekens et al. (1999) & \multicolumn{7}{c}{$I_{C}$ from sparse Gash model } \\
\cline { 2 - 7 } & 3.3 & 12.9 & 32.0 & 48.1 & 3.7 \\
Present study (sub-canopy) & 5 & 3 & 27 & 60 & 5 \\
Carlyle-Moses and Price (1999) & 5 & 8 & 84 & 8 & 0 \\
Van Dijk and Bruijnzeel (2001) & 0 & 8 & \multicolumn{5}{c}{}
\end{tabular}

I, Evaporation from events in which rainfall was insufficient to saturate the canopy; II, Wetting up of canopy; III, Evaporation from canopy during storms; IV, Evaporation from canopy after storms; $\mathrm{V}$, Evaporation from trunks and stems.

sub-canopy layer does not vary significantly because the upper canopy reduces the dependence of $S$ on rainfall intensity by homogenizing the size distribution of raindrops prior to contact with the lower layers (Link et al., 2004).

Canopy storage capacity $(S)$ in the top-canopy is almost two times that in the sub-canopy layer in Shaoshan mixed forest, which indicates that $S$ is more variable in the topcanopy than that in the sub-canopy. Also, in the sub-canopy probably average drop-size is large. In deciduous forests, wind speed was demonstrated to reduce $S$ by the mechanical shaking of the canopy elements (Hörmann et al., 1996), while Link et al. (2004) found no relationship between $S$ and wind speed during an event study in an old-growth Douglasfir-western hemlock ecosystem. In some conifer forests, Calder (1996) found that canopy storage capacity $(S)$, varied dynamically with rainfall intensity and suggested that $S_{c}$ is a function of raindrop size and thus rainfall intensity, with $S_{c}$ being reduced when raindrop volumes and associated kinetic energies are large.

The sensitivity of $c$ and $S$ in our study is similar to the analysis of Gash et al. (1995), which shows that the simulated interception loss is the most sensitive to the value of the canopy cover $(c)$, followed by a lower sensitivity to the canopy storage capacity $(S)$. The modelled interception loss was fairly insensitive to the stemflow parameters, $S_{t}, p_{d}$ and $\varepsilon$.

\subsection{Evaporation rate}

The values of $\bar{E}$ and $\bar{E}_{c}$ are within typical range of $0.15 \mathrm{~mm} \cdot \mathrm{h}^{-1}$ (Lousteau et al., 1992 ) to $0.65 \mathrm{~mm} \cdot \mathrm{h}^{-1}$ (Valente et al., 1997). Gash et al. (1995) reported that the wet canopy evaporation rate is directly related to the canopy coverage. The evaporation rate per unit cover area improves the agreement between the estimated and measured interception loss (Gash et al., 1995; Valente et al., 1997), which may explain the accurate estimates of the sub-canopy interception loss compared with that in the top-canopy.

It is noted that evaporation from stem and trunks in Shaoshan study was slight, accounting for 8.1 and $3.7 \%$ of the estimated interception loss in top- and sub-canopy, respectively. Rutter and Morton (1975) suggested the evaporation from stems (on a projected area basis) to be only $2 \%$ of wet canopy evaporation rate. However, van Dijk and Bruijnzeel (2001) reported that evaporation from wetted stems during a storm had a significant impact on the relative magnitude of the interception loss and argued that evaporation rate from wetted stems equaled to that from the wetted canopy.

\subsection{Canopy interception loss}

With regard to the interception losses, the original Gash model overestimated the top-canopy interception by $17.2 \%$; in contrast, the sparse model gave an accurate estimate for the sub-canopy loss $(7.0 \%)$ (Table 4$)$.

Table 5 shows that in previous studies $10 \sim 54 \%$ of the calculated interception loss by the original Gash model and $8 \sim 60 \%$ by the sparse model occurred in the stage of "after storms", and $27 \sim 82 \%$ and $27 \sim 84 \%$ were in the "during storms" stage, respectively. In our present study, the modelled top-canopy losses in the "during storms" stage accounted for $54.7 \%$ of the estimated loss and that in the "after storms" phase was $27.2 \%$, which were in agreement with the previous results (Table 5). Furthermore, for the sub-canopy interception, $32 \%$ of the estimated interception in the "during storms" stage and $48 \%$ in the "after storms" stage agreed well with the reported ranges (Table 5).

There is an increasing number of studies report that wet canopy evaporation rates inferred from throughfall measurements are much higher than that derived from PenmanMonteith theory (Rowe, 1983; Vrugt et al., 2003; Keim, 2004). Gash and Morton (1978), using the original analytical model with Penman-Monteith equation in England, found that the interception loss was overestimated by $6.9 \%$. Moreover, Gash et al. (1980) found large difference between observed and modelled values for three coniferous forests in UK, although the value for the mean evaporation rate was within $20 \%$ level of confidence. Rowe (1983) found the Gash model overestimated interception loss by $3.4 \%$ in a evergreen mixed forest in New Zealand, while Hörmann et al. (1996) concluded, introducing a wind dependent storage capacity, that the Gash model overestimated observed 
interception loss by 5.4\% in beech forests in northern Germany. In our Shaoshan forest study, the total estimated interception loss by combining of the original Gash model and the sparse model overestimated the total measured loss by $13.5 \%$, which is slightly higher than the reported results.

\subsection{Application of the groups of the Gash models}

The main weakness of the reformulated Gash model is probably the assumption that the evaporation for the saturated canopy of a sparse forest can be estimated adequately by the Penman-Monteith equation. The application of the Penman-Monteith equation to simulate the evaporation rate requires good description of the internal layer resistance of the canopy. In addition, the stability correction for aerodynamic resistance above forests cannot be neglected, as usually assumed. Valente et al. (1997) has found that the interception loss in pine stands was usually higher that that in eucalypt forests, where the higher interception loss from pine forests can be attributed to their large canopy storage and the large aerodynamic conductance resulting from their height.

The method used to derive the value of $\bar{R}$ should be chosen carefully, whereas the value of $\bar{E}_{c}$ seems to be relatively stable. For short time-steps a smaller bucket size should probably be used (Gash et al., 1995, 1999; Valente et al., 1997; Jackson, 2000).

\section{Conclusions}

The original Gash analytical model and the sparse Gash model have been combined to simulate rainfall interception loss from the top- and sub-canopy layers in Shaoshan forest, central-south China in 2003. The total estimated interception loss from the two canopy layers was $334.1 \mathrm{~mm}$ with an error of $39.8 \mathrm{~mm}$ or $13.5 \%$ of total measured loss $(294.3 \mathrm{~mm})$. Both models overestimated the canopy interception losses relative to the measured values. The simulated top-canopy interception losses by the original Gash model was $215.6 \mathrm{~mm}$ with an overestimation of $17.2 \%$ of the measured losses and that estimated by the sparse model in subcanopy was $118.5 \mathrm{~mm}$ with an overestimation of $7.0 \%$.

The Gash model parameters derived from the two canopy layers in this study were similar to those in other forest studies. The modelled interception losses in the stages of "during storms" and "after storms" were in good agreement with the published results.

\section{List of symbols}

\begin{tabular}{|c|c|}
\hline$P_{G}$ & gross precipitation $(\mathrm{mm})$ \\
\hline$P_{G}^{\prime}$ & $\begin{array}{l}\text { gross precipitation necessary to saturate the } \\
\text { canopy }(\mathrm{mm})\end{array}$ \\
\hline$p$ & free throughfall coefficient (dimensionless) \\
\hline$p_{t}$ & stemflow portioning coefficient (dimensionless) \\
\hline$S$ & canopy storage capacity $(\mathrm{mm})$ \\
\hline$S_{c}$ & $\begin{array}{l}\text { canopy storage capacity scaling by canopy cover } \\
(\mathrm{mm})\end{array}$ \\
\hline$S_{t}$ & stem and trunk storage capacity $(\mathrm{mm})$ \\
\hline 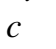 & canopy coverage (dimensionless) \\
\hline $\bar{E}$ & average evaporation rate $\left(\mathrm{mm} \cdot \mathrm{h}^{-1}\right)$ \\
\hline $\bar{E}_{c}$ & $\begin{array}{l}\text { average evaporation rate scaling by canopy cover } \\
\left(\mathrm{mm} \cdot \mathrm{h}^{-1}\right)\end{array}$ \\
\hline $\bar{R}$ & average rainfall intensity $\left(\mathrm{mm} \cdot \mathrm{h}^{-1}\right)$ \\
\hline$p_{d}$ & drainage partitioning coefficient (dimensionless) \\
\hline$n$ & $\begin{array}{l}\text { number of rainfall sufficient to saturate the } \\
\text { canopy (dimensionless) }\end{array}$ \\
\hline$m$ & $\begin{array}{l}\text { number of rainfall insufficient to saturate the } \\
\text { canopy (dimensionless) }\end{array}$ \\
\hline$q$ & $\begin{array}{l}\text { number of rainfall sufficient to saturate the } \\
\text { stems and trunks (dimensionless) }\end{array}$ \\
\hline
\end{tabular}

Acknowledgements. The study was financially supported by the National 863 High Technologies Research Foundation of China (No. 2004AA649370), the National Basic Research Program (973 Program) (No. 2005CB724203), the Natural Foundation for Distinguished Young Scholars (No. 50425927, No. 50225926), the Teaching and Research Award Program for Outstanding Young Teachers in Higher Education Institutions of MOE, P.R.C. (TRAPOYT) in 2000. The authors are also grateful to two anonymous reviewers and $\mathrm{M}$. Bierkens whose comments have greatly improved the quality of this paper.

Edited by: M. Bierkens

\section{References}

Aboal, J. R., Jiménez, M. S., Morales, D., and Hernndez, J. M.: Rainfall interception in laurel forest in the Canary Islands, Agric. For. Meteorol., 97, 73-86, 1999.

Acreman, M. C., Harding, R. J., Lloyd, C. R., and McNeil, D. D.: Evaporation characteristics of wetlands: experience from a wet grassland and a reedbed using eddy correlation measurements, Hydrol. Earth Syst. Sci., 7, 11-21, 2003, SRef-ID: 1607-7938/hess/2003-7-11.

Barbour, M. M., Hunt, J. E., Walcroft, A. S., Rogers, G. N. D., Mc Seveny, T. M., and Whitehead, D.: Components of ecosystem evaporation in a temperate coniferous rainforest, with canopy transpiration scaled using sapwood density, New Phytol., 165, 549-558, 2005.

Calder, L. R.: Evaporation in the uplands, Wiley, New York, 1990.

Calder, L. R.: Dependence of rainfall interception on drop size, 1. Development of the two-layer stochastic model, J. Hydrol., 185, 363-378, 1996.

Calder, I. R. and Hall, R. L.: Comment on "Interception of tropical rain forest: Performance of a canopy water balance model" by Jetten V. G., Hydrol. Processes, 11, 225-226, 1997. 
Carlyle-Moses, D. E. and Price, A. G.: An evaluation of the Gas interception model in a northern hardwood stand, J. Hydrol., 214, 103-110, 1999.

Carlyle-Moses, D. E.: A reply to R. Keim's comment on "Measurement and modeling of growing-season canopy water fluxes in a mature mixed deciduous forest stand, southern Ontario, Canada", Agric. Forest Meteorol., 124, 281-284, 2004.

Cui, J. B., Li, C. S., and Carl, T.: Analyzing the ecosystem carbon and hydrologic characteristics of forested wetland using a biogeochemical process model, Global Change Biol. 11, 278-289, 2005.

Dolman, A. J.: Evaporation from an oak forest, $\mathrm{PhD}$ thesis University of Groningen, The Netherlands, 1988.

Domingo, F., Sánchez, G., Moro, M. J., Brenner, A. J., and Puigdefábregas, J.: Measurement and modeling of rainfall interception by three semi-arid canopies, Agric. For. Meteorol., 91, 275-292, 1998.

Dykes, A. P.: Rainfall interception from a lowland tropical rainforest in Brunei, J. Hydrol., 200, 260-279, 1997.

EMEP/CCC: EMEP Manual for Sampling and Chemical Analysis, Norwegian Institute for Air Research, EMEP/CCC-Report 1/95, 1996.

Gash, J. H. C.: An analytical model of rainfall interception in forest, Q. J. R. Meteorol. Soc., 105, 43-55, 1979.

Gash, J. H. C., Lloyd, C. R., and Lachaud, G.: Estimating sparse forest rainfall interception with an analytical model, J. Hydrol., 170, 79-86, 1995.

Gash, J. H. C. and Morton, A. J.: An application of the Rutter model to the estimation of the interception loss from Thetford forest, J. Hydrol., 38, 49-58, 1978.

Gash, J. H. C., Valente, F., and David, J. S.: Esitmates and measurements of evaporation from wet, sparse pine forest in Portugal, Agric. For. Meteorol., 94, 149-158, 1999.

Gash, J. H. C., Wright, I. R., and Lloyd, C. R.: Comparative estimates of interception loss from three coniferous forests in Great Britain, J. Hydrol., 48, 89-105, 1980.

Hörmann, G., Branding, A., Clemen, T., Herbst, M., Hinrichs, A., and Thamm, F.: Calculation and simulating of wind controlled canopy interception of a beech forest in Northern Germany, Agric. For. Meteorol., 79, 131-148, 1996.

Hutjes, R. W. A., Wierda, A., and Veen, A. W. L.: Rainfall interception in the Tai forest, Ivory coast, Application of two simulation models to a humid tropical system, J. Hydrol., 114, 259-275, 1990.

Jackson, N. A.: Measured and modelled rainfall interception loss from an agroforesry system in Kenya, Agric. For. Meteorol., 100, 323-336, 2000.

Jetten, V. G.: Interception of tropical forest: performance of a canopy water balance model, Hydrol. Process., 10, 671-685, 1996.

Keim, R. F.: Comment on "Measuremnt and modeling of growingseason canopy water fluxes in a mature mixed deciduous forest stand, southern Ontario, Canada" by Price A. G. and CarlyeMoses D. E., Agric. Forest Meteorol., 124, 277-279, 2004.

Kelliher, F. M., Black, T. A., and Price, D. T.: Estimating the effect of understory removal from a Douglas fir forest using a two-layer canopy evapotranspiration model, Water Resour Res., 22, 18911899, 1986.

Kelliher, F. M., Whitehead, D., McAneney, K. J., and Judd, M.
J.: Partitioning evaporanspiration into understory components in two young Pinus radiato D. Don stands, Agric. For. Meteorol., 50, 211-227, 1990.

Klaassen, W., Boseveld, F., and De Water, E.: Water storage and evaporation as constituents of rainfall interception, J. Hydrol., 212-213, 36-50, 1998.

Lankreijer, H., Lundberg, A., Grelle, A., Lindroth, A., and Seibert, J.: Evaporation and storage of interception rain analyzed by comparing two models applied to a boreal forest, Agric. For. Meteorol., 98-99, 595-604, 1999.

Lankreijer, H., Hendriks, M. J., and Klaassen, W.: A comparison of models simulating rainfall interception of forests, Agric. For. Meteorol., 64, 187-199, 1993.

Leyton, L., Reynolds, E. R. C., and Thompson, F. B.: Rainfall interception in forests and moorland, in: Forest Hydrology, edited by: Sopper, W. E. and Lull, H. W., Pergamon, Oxford, 1967.

Link, T. E., Unsworth, M., and Marks, D.: The dynamics of rainfall interception by a seasonal temperate rainforest, Agric. For. Meteorol., 124, 171-191, 2004.

Lloyd, G. R., Gash, J. H. C., Shuttleworth, W. J., and Marquesde, A. O.: The measurement and modeling of rainfall interception by Amazonian rain forest, Agric. For. Meteorol., 43, 277-294, 1988.

Lousteau, D., Berbigier, P., and Granier, A.: Interception loss, throughfall and stemflow in a maritime pine stand, II. An application of Gash's analytical model of interception, J. Hydrol., 138, 469-485, 1992.

Mahendrappa, M. K.: Partitioning of rain water and chemicals into throughfall and stemflow in different forest stands, For. Ecol. Manage., 30, 65-72, 1990.

Návar, J. and Bryan, R. B.: Fitting the analytical model of rainfall interception of Gash to individual shrubs of semi-arid vegetation in northern Mexico, Agric. For. Meteorol., 68, 133-143, 1994.

Pearce, A. J. and Rowe, I. K.: Rainfall interception in a multistoried evergreen mixed forest: estimates using Gash's analytical model, J. Hydrol., 49, 341-353, 1981.

Price, A. G. and Carlyle-Moses, D. E.: Measurement and modeling of growing-season canopy water fluxes in a mature mixed deciduous forest stand, south Ontario, Canada. Agric. For. Meteorol., 119, 69-85, 2003.

Robin, L. H.: Interception loss as a function of rainfall and forest types: stochastic modeling for tropical canopies revisited, J. Hydrol., 280, 1-12, 2003.

Rosenbluth, E.: Point estimates for probability moments, Pro. Nat. Acad. Sci. USA, 72, 3812-3814, 1975.

Rowe, L. K.: Rainfall interception by an evergreen beech forest Nelson, New Zealand, J. Hydrol., 66, 143-158, 1983.

Rutter, A. J., Morton, A. J., and Robins, P. C.: A predictive model of rainfall interception in forests, II. Generalization of the model and comparison with observations in some coniferous and hardwood stands, J. Appl. Ecol., 12, 367-384, 1975.

Rutter, A. J., Kershww, K. A., Robins P. C., and Morton, A. J.: A predictive model of rainfall interception in forests 1 , derivation of the model from observations in a stand of Coriscan pine, Agric. Meteorol., 9, 367-384, 1971.

Schellekens, J., Scatena, F. N., Bruijnzeel, L. A., and Wickel, A. J.: Modelling rainfall interception by a lowland tropical rain forest in northeastern Puerto Rico, J. Hydrol., 225, 168-184, 1999.

Teklehaimonot Z. and Jarvis, P. G.: Modelling of rainfall intercep- 
tion loss on agroforestry systems, Agric. Sys., 14, 65-80, 1991.

Thimonier, A.: Measuring of atmospheric deposition under forest canopies: some recommendations for equipment and sampling design, Environ. Monitor. Assess., 52, 353-387, 1998.

Tobón, M., Bouten, C. W., and Serink, J.: Gross rainfall and its portioning into throughfall, stemflow and evaporation of intercepted water in four forest ecosystems in western Amazionia, J. Hydrol., 237, 40-57, 2000.

Valente, F., David, J. J. M., and Gash, J. H. C.: Modeling interception loss for two sparse eucalypt and pine forests in central Portugal using reformulated Rutter and Gash analytical models, J. Hydrol., 190, 141-162, 1997.

Van Dijk, A. I. J. M. and Bruijnzeel, L. A.: Modelling rainfall interception by vegetation of variable density using an adapted analytical model, Part 1. Model description, J. Hydrol., 247, 230-238, 2001.

Van Dijk, A. I. J. M. and Bruijnzeel, L. A.: Modelling rainfall interception by vegetation of variable density using an adapted analytical model. Part 2. Model validation for a tropical upland mixed cropping system, J. Hydrol., 247, 239-262, 2001.
Vrugt, J. C., Dekker, S. C., and Bouten, W.: Identification of rainfall interception model parameters from measurements of throughfall and forest canopy storage, Water Resource Res., 39, 1251-1259, 2003.

Whitehead, D. and Kelliher, F. M.: A canopy water balance model for a Pinus adiata stand before and after thinning, Agric. For. Meteorol., 55, 109-123, 1991.

Wright, R. F., Cosby, B. J., Flaten, M. B., and Reuss, J. O.: Evaluation of an acidification model with data from manipulated catchments in Norway, Nature, 343, 53-55, 1990.

Zeng, G. M., Zhang, G., Huang, G. H., Jiang, Y. M., and Liu, H. L.: Exchange of $\mathrm{Ca}^{2+}, \mathrm{Mg}^{2+}$ and $\mathrm{K}^{+}$and the uptake of $\mathrm{H}^{+}, \mathrm{NH}_{4}^{+}$ for the canopies in the subtropical forest influenced by the acid rain in Shaoshan forest located in central south China, Plant Sci., 168, 259-266, 2005.

Zhang, G., Zeng, G. M., Jiang, Y. M., Yao, J. M., Huang, G. H., Jiang, X. Y., Tan, W., Zhang, X. L., and Zeng, M.: Effects of weak acids on canopy leaching and uptake processes in a coniferous-deciduous mixed evergreen forest in central-south China, Water Air Soil Pollut., in press, doi:10.1007/s11270-0059044-3, 2005. 